\title{
Pathologic, Cytogenetic and Molecular Assessment of Acute Promyelocytic Leukemia Patients Treated with Arsenic Trioxide $\left(\mathrm{As}_{2} \mathrm{O}_{3}\right)$
}

Tao Zhang M.D., Ph.D., Peter Westervelt, M.D., Ph.D., Jay L. Hess, M.D., Ph.D.

Department of Pathology and Laboratory Medicine, Indiana University School of Medicine, Indianapolis, Indiana (TZ); Department of Medicine, Washington University School of Medicine, St. Louis, Missouri (PW); and Department of Pathology and Laboratory Medicine, University of Pennsylvania School of Medicine, Philadelphia, Pennsylvania (JLH)

Arsenic trioxide $\left(\mathrm{As}_{2} \mathrm{O}_{3}\right)$ shows great promise as an effective therapy for patients with all-trans retinoic acid (ATRA)-resistant acute promyelocytic leukemia (APL). Little data is available addressing the pathology of $\mathrm{As}_{2} \mathrm{O}_{3}$ treated APL and whether the antileukemic mechanism of $\mathrm{As}_{2} \mathrm{O}_{3}$ is primarily cytolysis or through stimulation of cell differentiation. In this report, we made a morphologic, cytogenetic, and molecular evaluation of five ATRA-refractory APL patients who were treated with $\mathrm{As}_{2} \mathrm{O}_{3}$. Four of the five patients had morphologic responses after one or two cycles of $\mathrm{As}_{2} \mathrm{O}_{3}$ treatment. Of the four responders based on bone marrow morphology, two achieved molecular remission (negative RT-PCR for PML- RAR $\alpha$ fusion transcripts) by the end of the second and third cycles of $\mathrm{As}_{2} \mathrm{O}_{3}$ therapy. Two patients exhibited marked leukocytosis during the first cycle of $\mathrm{As}_{2} \mathrm{O}_{3}$, and at that time point the APL cells were largely replaced by the cells showing partial differentiation towards myelocytes with coexpression of CD11b and CD33. Nevertheless, these "myelocyte-like" cells that showed the $t(15 ; 17)$ translocation eventually disappeared with continuous $\mathrm{As}_{2} \mathrm{O}_{3}$ therapy. $\mathrm{As}_{2} \mathrm{O}_{3}$ treatment appears to be effective therapy for the patients with relapsed APL after the failure of conventional chemotherapy and ATRA therapy. The pathologic findings in these five cases suggest that at low doses $\mathrm{As}_{2} \mathrm{O}_{3}$ primarily induces differentiation of the APL cells, generating abnormal myelocytes resembling APL cells treated with ATRA, whereas at higher doses $\mathrm{As}_{2} \mathrm{O}_{3}$ induces marrow necrosis.

Copyright () 2000 by The United States and Canadian Academy of Pathology, Inc.

VOL. 13, NO. 9, P. 954, 2000 Printed in the U.S.A.

Date of acceptance: April 6, 2000.

Address reprint requests to: Jay L. Hess, M.D., Ph.D., Department of Pathology and Laboratory Medicine, Division of Anatomic Pathology, 3400 Spruce Street, Founders 6, Philadelphia, PA 19104-4283; e-mail: jhess@mail.med.upenn.edu; fax: 215-349-5910.
KEY WORDS: Acute promyelocytic leukemia, Alltrans retinoic acid, Arsenic trioxide.

Mod Pathol 2000;13(9):954-961

Acute promyelocytic leukemia (APL), which accounts for approximately $10 \%$ of all acute myeloid leukemia (AML) cases, is defined by the $\mathrm{t}(15 ; 17)$ chromosomal translocation, which fuses the promyelocytic leukemia protein (PML) gene located on chromosome 15q22 to the retinoic acid receptor $\alpha$ $(\operatorname{RAR} \alpha)$ gene on chromosome $17 \mathrm{q} 21$ (1). The resulting PML-RAR $\alpha$ fusion protein plays a key role in leukemogenesis by blocking neutrophilic differentiation at the promyelocyte stage. APL cells undergo terminal differentiation upon treatment with alltrans retinoic acid (ATRA) both in vitro and in vivo (2), making ATRA the first-line drug for inducing complete remission in APL patients (3-5). However, a significant percentage (20 to $30 \%$ ) of patients relapse after initial remission and subsequently develop resistance to ATRA treatment (4-5). The clinical outcome of those patients is quite poor, as no effective therapy is available for ATRA-resistant APL. Recently, arsenic trioxide $\left(\mathrm{As}_{2} \mathrm{O}_{3}\right)$, an active component of antileukemic drugs in traditional Chinese medicine, was found to induce complete remission in both ATRA-sensitive and -resistant APL patients (6-8). The antileukemic mechanism of $\mathrm{As}_{2} \mathrm{O}_{3}$ is under active investigation. Studies have shown that at micromolar concentrations $\mathrm{As}_{2} \mathrm{O}_{3}$ triggers apoptosis of APL cells in association with the down-regulation of bcl-2 protein (9-14), whereas at lower concentrations it induces partial differentiation (6). In APL cells, $\mathrm{As}_{2} \mathrm{O}_{3}$ rapidly induces a dramatic reorganization of APL-specific PML or PML/RAR $\alpha$-associated microparticulate structures into fewer larger subnuclear spots followed by a progressive degradation of PML/RAR $\alpha$ protein $(9-11,14-16)$. Limited data is available addressing the pathology of $\mathrm{As}_{2} \mathrm{O}_{3}$ treated APL and 
TABLE 1. Demographic and Clinical Data of Patients with APL before Arsenic Trioxide Therapy

\begin{tabular}{|c|c|c|c|c|c|c|}
\hline $\begin{array}{l}\text { Patient } \\
\text { No. }\end{array}$ & $\begin{array}{l}\text { Age } \\
\text { (years) }\end{array}$ & Sex & $\begin{array}{c}\mathrm{FAB} \\
\text { Classification }\end{array}$ & Cytogenetics & $\begin{array}{c}\text { Treatment Before } \\
\mathrm{AS}_{2} \mathrm{O}_{3}\end{array}$ & $\begin{array}{l}\text { No. of } \\
\text { Relapses }\end{array}$ \\
\hline 1 & 32 & F & M3v & $46, \mathrm{XX}, \mathrm{t}(15 ; 17)(\mathrm{q} 22 ; \mathrm{q} 11-12),+8$ & $\begin{array}{l}\text { Conventional } \\
\text { chemotherapy, } \\
\text { ATRA, auto-PBSC } \\
\text { BMT }(\times 1)\end{array}$ & 3 \\
\hline 2 & 34 & M & M3v & $47, \mathrm{XY}, \mathrm{t}(15 ; 17)(\mathrm{q} 22 ; \mathrm{q} 11.2),+21$ & $\begin{array}{l}\text { Conventional } \\
\text { chemotherapy, } \\
\text { ATRA }\end{array}$ & 2 \\
\hline 3 & 35 & M & M3v & $\begin{array}{l}\text { 46, XY, t(2;15;17)(p21;q22;q12), } \\
\quad \operatorname{inv}(3)(\mathrm{p} 23 \mathrm{q} 25), \operatorname{del}(6)(\mathrm{q} 22)\end{array}$ & $\begin{array}{l}\text { Conventional } \\
\text { chemotherapy, } \\
\text { ATRA, allo- } \\
\text { BMT }(\times 2)\end{array}$ & 3 \\
\hline 4 & 70 & M & M3 & $\begin{array}{l}\text { 47, XY, t(15;17)(q22;q12), } \\
\quad \text { add(16)(q22), add(17)(p11), } \\
\quad+\text { mar }\end{array}$ & $\begin{array}{l}\text { Conventional } \\
\text { chemotherapy, } \\
\text { ATRA }\end{array}$ & 2 \\
\hline 5 & 54 & M & M3 & $46, \mathrm{XY}, \mathrm{t}(15 ; 17)(\mathrm{q} 22 ; \mathrm{q} 12)$ & $\begin{array}{l}\text { Conventional } \\
\text { chemotherapy, } \\
\text { ATRA }\end{array}$ & 2 \\
\hline
\end{tabular}

The conventional chemotherapy includes ara-C, daunorubicin, or idarubicin.

Auto-PBSC BMT, autologous peripheral blood stem cell bone marrow transplantation; allo-BMT, allogeneic bone marrow transplantation.

whether the antileukemic mechanism of $\mathrm{As}_{2} \mathrm{O}_{3}$ is primarily cytolysis or through stimulation of cell differentiation. In this report, we examined the pathology of five refractory APL patients treated with $\mathrm{As}_{2} \mathrm{O}_{3}$ and correlated this with the cytogenetic and molecular findings.

\section{MATERIALS AND METHODS}

\section{Clinical Protocol and Patients}

The APL patients studied were all enrolled in a phase I/II trial of intravenous infusion of $\mathrm{As}_{2} \mathrm{O}_{3}$ for treatment of relapsed APL (Washington University

TABLE 2. Summary of Clinical, Morphologic, Cytogenetic, and Molecular Responses of the Patients to Arsenic Trioxide Therapy

\begin{tabular}{|c|c|c|c|c|c|c|}
\hline $\begin{array}{l}\text { Patient } \\
\text { No. }\end{array}$ & Dose of $\mathrm{AS}_{2} \mathrm{O}_{3}$ & $\begin{array}{l}\text { Morphologic } \\
\text { Remission }\end{array}$ & $\begin{array}{l}\text { Cytogenetic } \\
\text { Remission }\end{array}$ & $\begin{array}{l}\text { Molecular } \\
\text { Remission }\end{array}$ & $\begin{array}{c}\text { Morphologic } \\
\text { Changes After } 1^{\text {st }} \\
\text { Cycle of } \mathrm{AS}_{2} \mathrm{O}_{3}\end{array}$ & $\begin{array}{l}\text { Clinical Follow- } \\
\text { Up }\end{array}$ \\
\hline 1 & $\begin{array}{l}0.08 \mathrm{mg} / \mathrm{kg} / \\
\text { day for } 11 \\
\text { day, and } 0.4 \\
\mathrm{mg} / \mathrm{kg} / \text { day } \\
\text { for } \\
\text { additional } \\
17 \text { days }\end{array}$ & $\begin{array}{l}\text { Yes (after } 1^{\text {st }} \\
\text { cycle) }\end{array}$ & $\begin{array}{c}\text { No (after } 1^{\text {st }} \\
\text { cycle) }\end{array}$ & $\begin{array}{c}\text { No (after } 1^{\text {st }} \\
\text { cycle) }\end{array}$ & $\begin{array}{l}\text { Alternating areas } \\
\text { of myeloid } \\
\text { hyperplasia } \\
\text { and } \\
\text { maturation, } \\
\text { and marrow } \\
\text { necrosis }\end{array}$ & $\begin{array}{l}\text { Relapsed } 4 \\
\text { months later, } \\
\text { and died } \\
\text { secondary to } \\
\text { intracranial } \\
\text { hemorrhage }\end{array}$ \\
\hline 2 & $0.1 \mathrm{mg} / \mathrm{kg} /$ day & N/A & N/A & N/A & $\begin{array}{l}\text { Hypercellular } \\
\text { marrow with } \\
\text { limited myeloid } \\
\text { differentiation }\end{array}$ & $\begin{array}{l}\text { Died secondary } \\
\text { to } \\
\text { pulmonary } \\
\text { hemorrhage } \\
\text { on day } 14 \text { of } \\
\mathrm{As}_{2} \mathrm{O}_{3} \\
\text { therapy }\end{array}$ \\
\hline 3 & $0.1 \mathrm{mg} / \mathrm{kg} /$ day & $\begin{array}{c}\text { Yes (after } 2^{\text {nd }} \\
\text { cycle) }\end{array}$ & $\begin{array}{l}\text { Yes (after } 2^{\text {nd }} \\
\text { cycle) }\end{array}$ & $\begin{array}{c}\text { Yes (after } 3^{\text {rd }} \\
\text { cycle) }\end{array}$ & $\begin{array}{l}\text { Myeloid } \\
\text { hyperplasia } \\
\text { with } \\
\text { maturation to } \\
\text { mainly } \\
\text { myelocyte } \\
\text { stage }\end{array}$ & $\begin{array}{l}\text { Relapsed } 2 \\
\text { months later } \\
\text { after } 3^{\text {rd }} \\
\text { cycle of } \\
\mathrm{As}_{2} \mathrm{O}_{3} \text {, and } \\
\text { died } \\
\text { secondary to } \\
\text { respiratory } \\
\text { failure }\end{array}$ \\
\hline 4 & $0.1 \mathrm{mg} / \mathrm{kg} /$ day & $\begin{array}{l}\text { Yes (after } 1^{\text {st }} \\
\text { cycle) }\end{array}$ & $\begin{array}{l}\text { Yes (after } 2^{\text {nd }} \\
\text { cycle) }\end{array}$ & $\begin{array}{l}\text { Yes (after } 2^{\text {nd }} \\
\text { cycle) }\end{array}$ & $\begin{array}{l}\text { Myeloid } \\
\text { differentiation, } \\
\text { without } \\
\text { hyperplasia }\end{array}$ & $\begin{array}{l}\text { In complete } \\
\text { remission }\end{array}$ \\
\hline 5 & $0.1 \mathrm{mg} / \mathrm{kg} /$ day & $\begin{array}{l}\text { Yes (after } 2^{\text {nd }} \\
\text { cycle) }\end{array}$ & $\begin{array}{l}\text { Yes (after } 2^{\text {nd }} \\
\text { cycle) }\end{array}$ & $\begin{array}{l}\text { No (after } 2^{\text {nd }} \\
\text { cycle) }\end{array}$ & $\begin{array}{l}\text { Myeloid } \\
\text { differentiation, } \\
\text { without } \\
\text { hyperplasia }\end{array}$ & $\begin{array}{l}\text { In clinical and } \\
\text { hematologic } \\
\text { remission }\end{array}$ \\
\hline
\end{tabular}

N/A, not available (patient 2 died before completion of the first cycle). 
TABLE 3. Changes of Peripheral White Blood Cell Counts Before and After Treatment with $\mathrm{As}_{2} \mathrm{O}_{3}$

\begin{tabular}{cccc}
\hline & \multicolumn{3}{c}{ White Blood Cell Counts $\left(\times 10^{9} / \mathrm{L}\right)$} \\
\cline { 2 - 4 } Patient No. & $\begin{array}{c}\text { Before } \\
\mathrm{As}_{2} \mathrm{O}_{3}\end{array}$ & $\begin{array}{c}2 \text { Weeks After } \\
\mathrm{As}_{2} \mathrm{O}_{3}\end{array}$ & $\begin{array}{c}\text { Weeks After } \\
\mathrm{As}_{2} \mathrm{O}_{3}\end{array}$ \\
\hline 1 & 5.0 & 180 & 17.0 \\
2 & 3.8 & 9.4 & N/A \\
3 & 8.1 & 9.8 & 19.2 \\
4 & 7.6 & 9.0 & 4.8 \\
5 & 3.0 & 1.5 & 2.6 \\
\hline
\end{tabular}

N/A, not available because the patient died secondary to pulmonary hemorrhage.

Protocol \#98-0185). An informed consent was obtained from all the patients. Patients with relapsed or primary refractory APL following conventional chemotherapy and ATRA who were not candidates for HLA-matched sibling bone marrow/stem cell transplantation were eligible for study entry. The diagnosis of all five patients in this report was based on FABAML criteria and flow cytometric immunophenotyping, and was further confirmed by cytogenetic analysis or by reverse transcription polymerase chain reaction (RT-PCR) assay that detected PML-RAR $\alpha$ fu- sion transcripts. Three of the five cases were further morphologically classified as the microgranular variant of APL (M3v). The patients' demographic and clinical data are shown in Table 1.

\section{Treatment with Arsenic Trioxide}

ACS reagent grade arsenic trioxide $\left(\mathrm{As}_{2} \mathrm{O}_{3}\right)$ was obtained from Sigma Chemical Co. (St. Louis, MO) and was administrated through continuous intravenous infusion for 28 days. Patient 1 was started $\mathrm{As}_{2} \mathrm{O}_{3}$ at $10 \mathrm{mg}$ daily $(0.08 \mathrm{mg} / \mathrm{kg} /$ day $)$ for the first 11 days and $50 \mathrm{mg}$ daily $(0.4 \mathrm{mg} / \mathrm{kg} /$ day $)$ for the additional 17 days, and the total $\mathrm{As}_{2} \mathrm{O}_{3}$ administered was $550 \mathrm{mg}$. The remaining four patients were treated with lower doses of $\mathrm{As}_{2} \mathrm{O}_{3}$, with the dosage based on actual body weight, starting at $0.1 \mathrm{mg} / \mathrm{kg} /$ day (Table 2).

Morphologic, Immunophenotypic, Cytogenetic, and Molecular Evaluation

EDTA-decalcified, formalin-fixed bone marrow

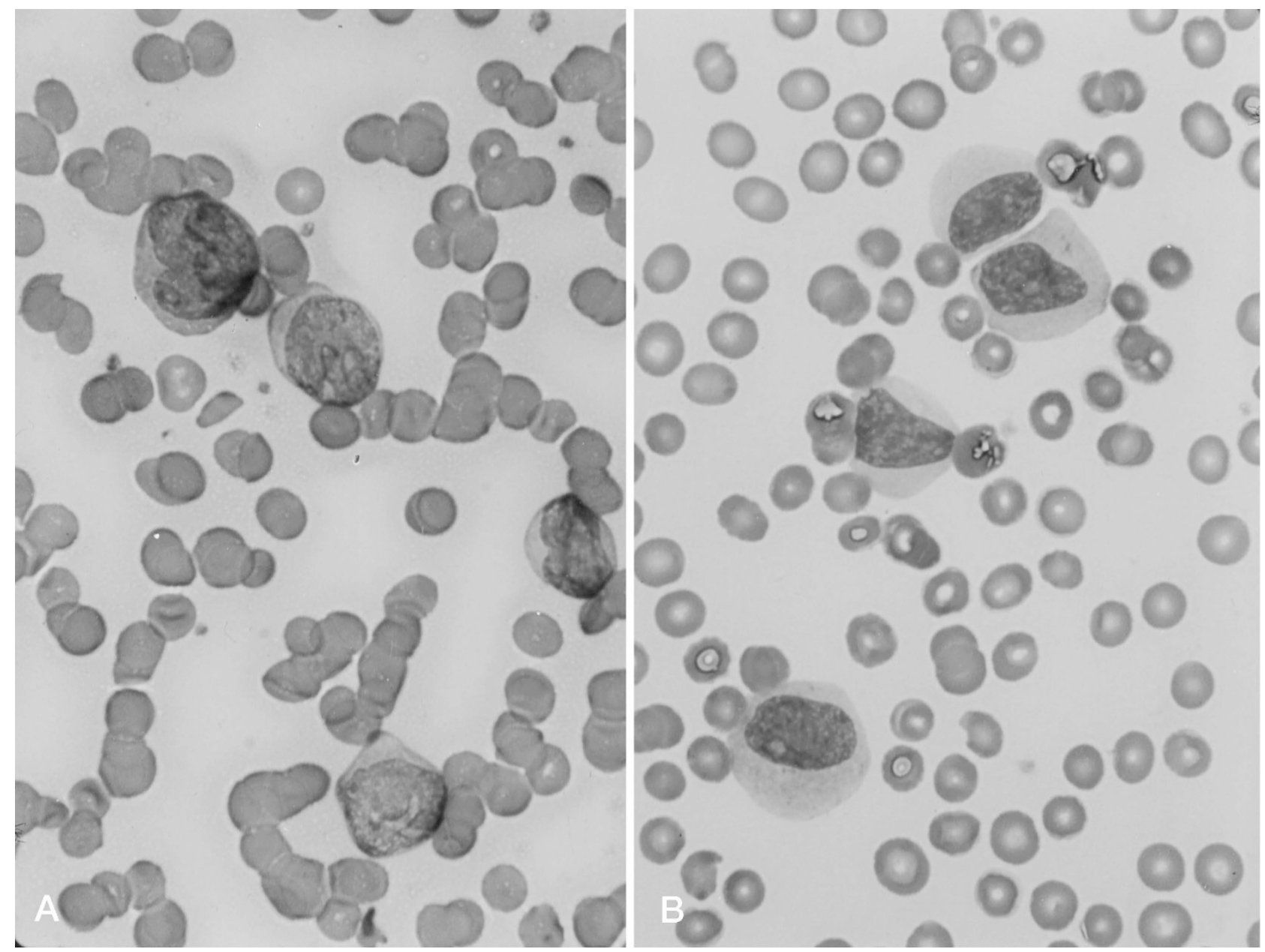

FIGURE 1. $\mathrm{As}_{2} \mathrm{O}_{3}$ treatment induces maturation of acute promyelocytic leukemic cells. Peripheral blood smears of patient 1 before (A) and 3 weeks after (B) $\mathrm{As}_{2} \mathrm{O}_{3}$ treatment (Wright-Giemsa stain; original magnification, 250×). 


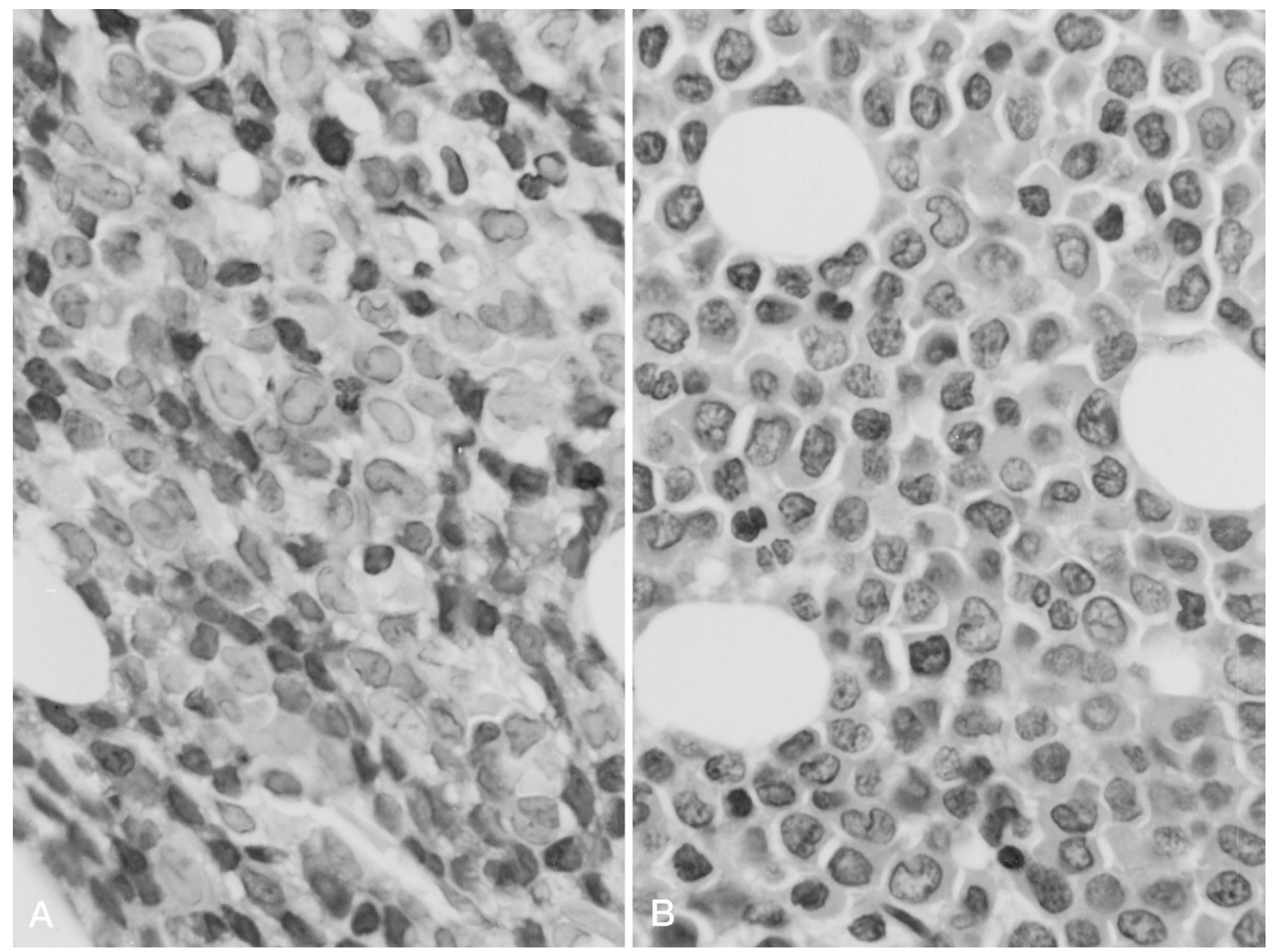

FIGURE 2. The bone marrow biopsies of patient 3 before and after the first cycle of $\mathrm{As}_{2} \mathrm{O}_{3}$ treatment. A, high-power view of bone marrow core section before $\mathrm{As}_{2} \mathrm{O}_{3}$ treatment showing Leder negative myeloblasts and dysplastic promyelocytes with high nucleocytoplasmic ratios, irregular nuclear contours and fine chromatin (Leder stain; original magnification, 250×); B, high-power view of bone marrow core section after the first cycle of $\mathrm{As}_{2} \mathrm{O}_{3}$ treatment, showing cells with slightly condensed chromatin and decreased nucleocytoplasmic ratio and occasional nucleoli, suggesting slight myeloid maturation (Leder stain; original magnification, $250 \times$ ).

core biopsy specimens were stained with hematoxylin-and-eosin and chloroacetate esterase (Leder) stains. Wright-Giemsa stained bone marrow aspirates and peripheral blood smears before and after therapy for each patient were reviewed. Immunophenotyping was performed by two-color flow cytometry using Ficoll-Paque purified cells stained with phycoerythrin (PE)-labeled anti-CD 33 monoclonal antibody and fluorescein isothiocyanate (FITC)labeled anti-CD11b monoclonal antibody (Coulter, Hialeah, FL) on Coulter EPICS ${ }^{\mathrm{TM}}$ XL-MCL instruments. Cytogenetic studies on metaphase spreads were performed according to standard techniques. Four of the five patients showed the characteristic $t(15 ; 17)$; one showed a complex three way translocation involving chromosomes 2, 15, and 17; and four patients showed additional cytogenetic abnormalities (Table 2). RT-PCR detection of PML/RAR $\alpha$ fusion mRNA was performed according to Miller, et al. (17). Morphologic, cytogenetic, and molecular evaluations were made before the therapy and after the completion of each cycle of $\mathrm{As}_{2} \mathrm{O}_{3}$ treatment.

\section{RESULTS}

\section{Peripheral Blood Findings}

Three of the five patients developed significant leukocytosis during the first month of $\mathrm{As}_{2} \mathrm{O}_{3}$ treatment (Table 3). For example, two weeks after initiation of the treatment patient 1 showed an increase in white blood cell count from the pretreatment levels of $5000 / \mathrm{mm}^{3}$ to $180,000 / \mathrm{mm}^{3}$, which necessitated leukopheresis. During the first two weeks of $\mathrm{As}_{2} \mathrm{O}_{3}$ treatment, the APL cells exhibited little maturation. However, with continuation of the therapy, the APL cells began to mature, showing significantly decreased nuclear-cytoplasmic ratio and condensed chromatin by the end of the first month (Fig. 1).

\section{Bone Marrow Findings}

After one cycle of $\mathrm{As}_{2} \mathrm{O}_{3}$ treatment, all the patients showed some degree of morphologic response. Two patients achieved morphologic remis- 


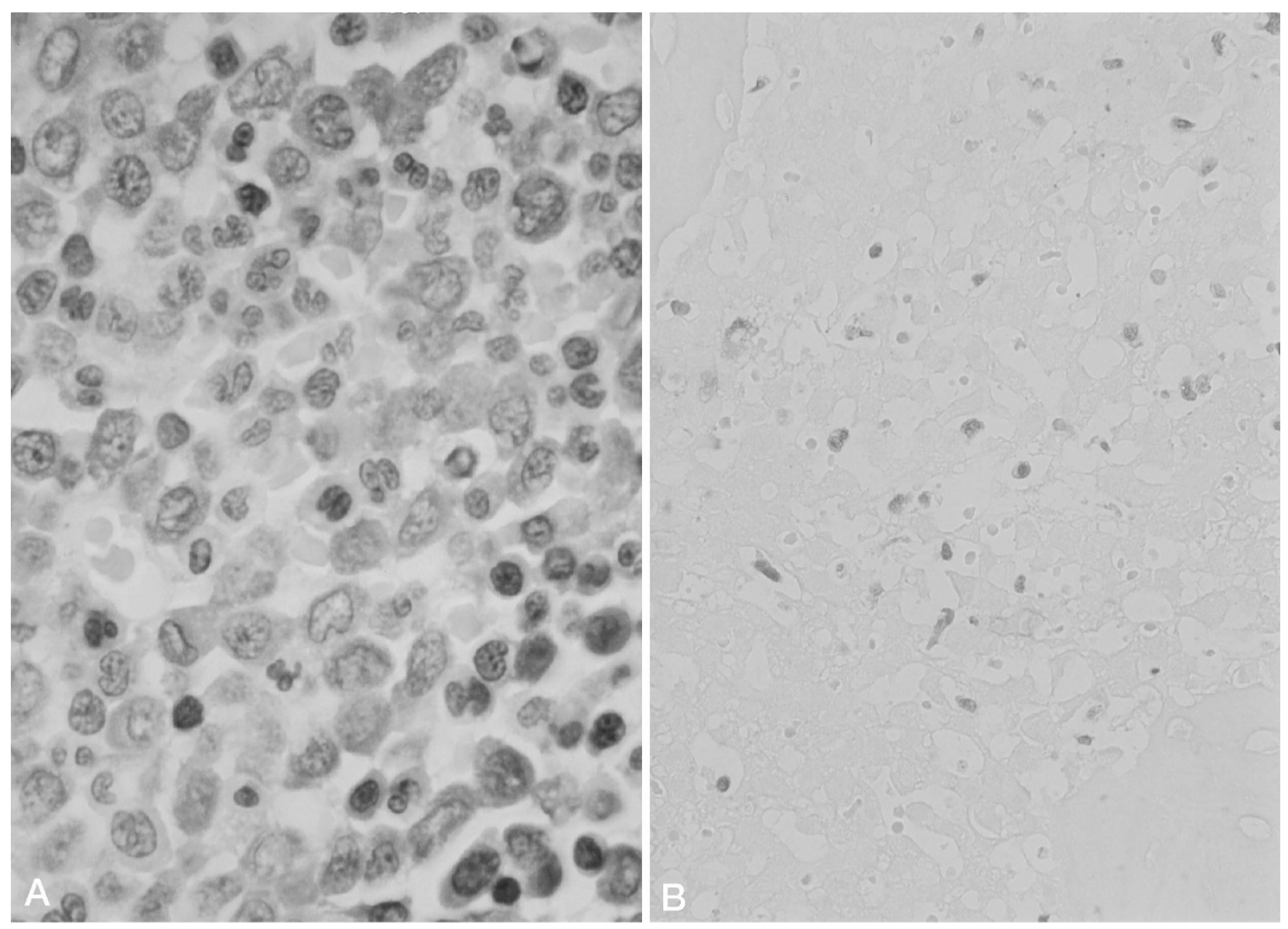

FIGURE 3. Bone marrow biopsy of patient 1 one month after treatment with high doses of $\mathrm{As}_{2} \mathrm{O}_{3}$. The marrow showed hypercellular areas showing trilineage hematopoiesis alternating with areas of necrosis. A, high-power view of hypercellular areas showing nearly normal hematopoiesis (Leder stain; original magnification, $250 \times$ ); and $\mathbf{B}$, high-power view of necrotic areas showing largely ghost cells, cellular debris, and occasional degenerating myeloid elements (Leder stain; original magnification, $150 \times$ ).

sion after the first cycle of therapy, and the other two patients also showed morphologic remission following two cycles of therapy. All marrowed showed a myeloid predominance and were normocellular or hypercellular. The APL cells differentiated to cells with a significantly lower N/C ratio, condensed chromatin, and sparsely granular cytoplasm, which closely resemble APL cells treated with ATRA (Fig. 2). With continuation of therapy, these "myelocyte-like" cells eventually disappeared and normal trilineage hematopoiesis resumed. In addition to the "myelocyte-like" cells, two other distinctive morphologic findings were seen in arsenic-treated patients. The first was bone marrow necrosis. Patient 1 showed geographic marrow necrosis alternating maturing granulocyte hyperplasia after the treatment of high doses of $\mathrm{As}_{2} \mathrm{O}_{3}(0.4 \mathrm{mg} /$ $\mathrm{kg}$ /day) (Fig. 3). This may be a dose-dependent effect as marrow necrosis was not seen in patients treated with lower doses of $\mathrm{As}_{2} \mathrm{O}_{3}(0.1 \mathrm{mg} / \mathrm{kg} /$ day $)$. A second unusual effect of arsenic was an altered appearance of regenerating non-neoplastic myeloid progenitors. After the second cycle of $\mathrm{As}_{2} \mathrm{O}_{3}$ therapy, bone marrows from two of the patients showed sheets of Leder positive atypical promyelocytes with oval to round nuclear contours, prominent nucleoli, and abundant granular cytoplasm (Fig. 4). At the same time, normal trilineage hematopoiesis was seen in the adjacent marrow tissue, and both the cytogenetic analysis and RT-PCR for PML-RAR $\alpha$ performed on the same bone marrow aspirate were negative. Furthermore, with continuous arsenic therapy, a subsequent bone marrow biopsy obtained one month later was unremarkable without these atypical promyelocytes.

\section{Flow Cytometric Findings}

Flow cytometric analysis was performed in patient 1 and patient 5 after completion of the first cycle of therapy and showed significantly increased numbers of myeloid elements that expressed CD11b, which is expressed at high levels on more mature granulocytic and monocytic cells, along with decreased expression of CD13 and CD33. However, predominant CD13 and CD33 expression with diminished expression of CD11b was also observed during relapse in patient 3 two months after 
completion of the third cycle of the treatment. On the forward scatter versus side scatter plots, the APL cells showed a dramatic shift from the typical blast gate to more mature myeloid cells following $\mathrm{As}_{2} \mathrm{O}_{3}$ treatment (Fig. 5).

\section{Clinical Follow-Up}

A summary of the morphologic cytogenetic, molecular, and clinical findings following therapy is given in Table 2. After one cycle of $\mathrm{As}_{2} \mathrm{O}_{3}$ treatment, patient 1 achieved morphologic remission although the cytogenetics remained positive for $t(15 ; 17)$. However, a bone marrow biopsy at four mo posttherapy showed relapse of APL and the patient expired one month later. An autopsy was not performed. The cause of death was suspected to be intracranial bleeding. Patient 2 developed fatal pulmonary hemorrhage in the setting of pneumonia and thrombocytopenia after 14 days of $\mathrm{As}_{2} \mathrm{O}_{3}$ treatment. Patient 3 successfully achieved molecular remission by the end of the third cycle of $\mathrm{As}_{2} \mathrm{O}_{3}$ therapy and remained disease free for approximately two mo after discontinuation of treatment before experiencing leukemic relapse. He died one month later of refractory respiratory failure. Patient 4 achieved molecular remission following two cycles of treatment and remains in molecular remission following completion of three cycles of $\mathrm{As}_{2} \mathrm{O}_{3}$ therapy. After the second cycle of $\mathrm{As}_{2} \mathrm{O}_{3}$ therapy, patient 5 is in morphologic and cytogenetic remission, although the RT-PCR assay performed on a recent bone marrow aspirate was positive for PML-RAR $\alpha$ fusion transcripts.

\section{DISCUSSION}

In this report, we evaluated the pathologic, cytogenetic, and molecular findings in five relapsed APL patients who were treated with $\mathrm{As}_{2} \mathrm{O}_{3}$ therapy. Our data has confirmed earlier reports that clinical and molecular remission can be achieved with $\mathrm{As}_{2} \mathrm{O}_{3}$ treatment in some ATRA-refractory APL patients (6-8). Our main focus in this study, however, was to better define the pathology of arsenic treatment of APL.

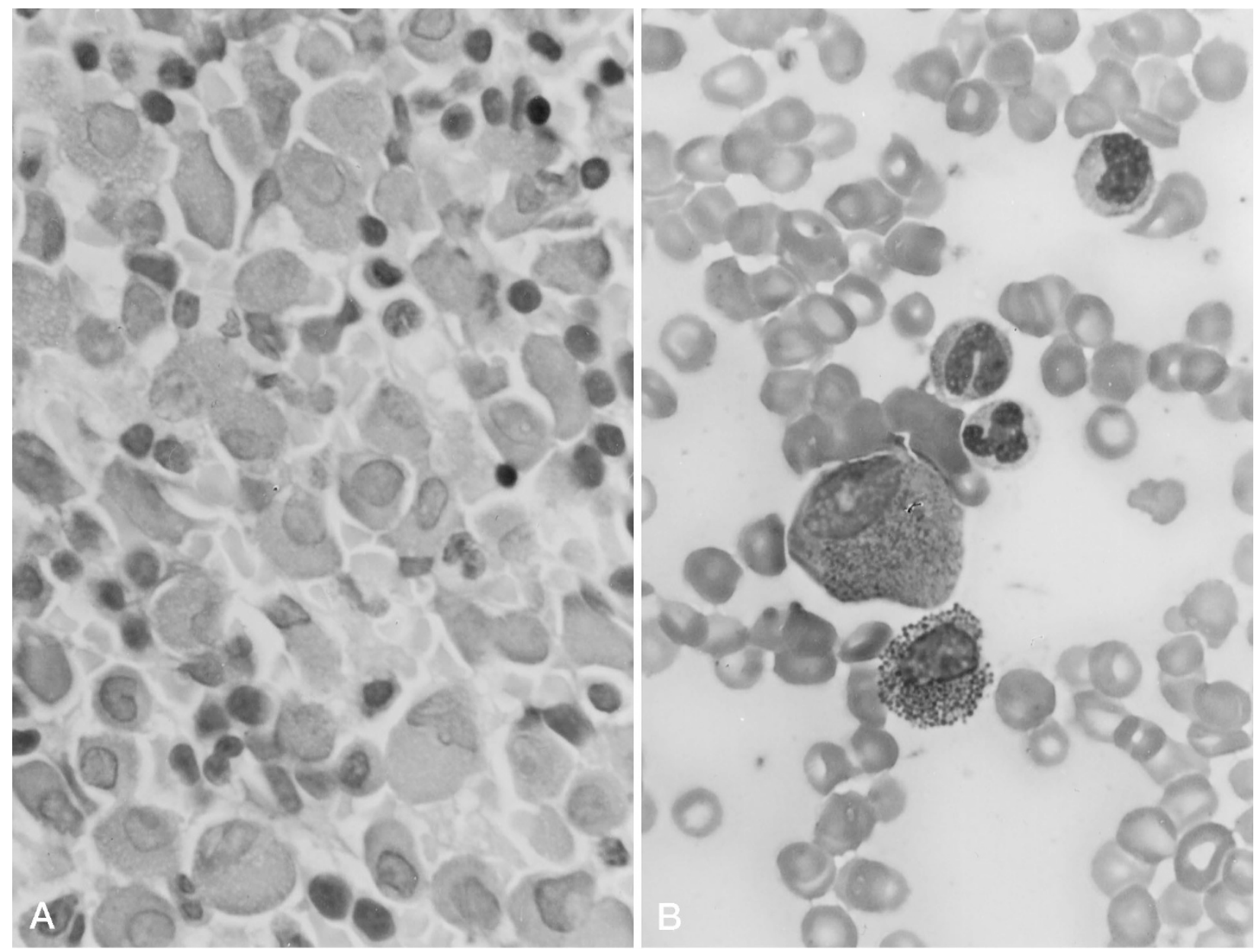

FIGURE 4. The bone marrow biopsy of patient 4 following two cycles of $\mathrm{As}_{2} \mathrm{O}_{3}$ treatment. A, bone marrow core section showing sheets of atypical promyelocytes with smooth round or oval nuclear contours, frequent prominent nucleoli, and abundant Leder positive granular cytoplasm (Leder stain; original magnification, $250 \times$ ); B, bone marrow aspirate showing a promyelocyte (center) with abundant granulated cytoplasm (Wright-Giemsa stain; original magnification, $250 \times)$. 
A

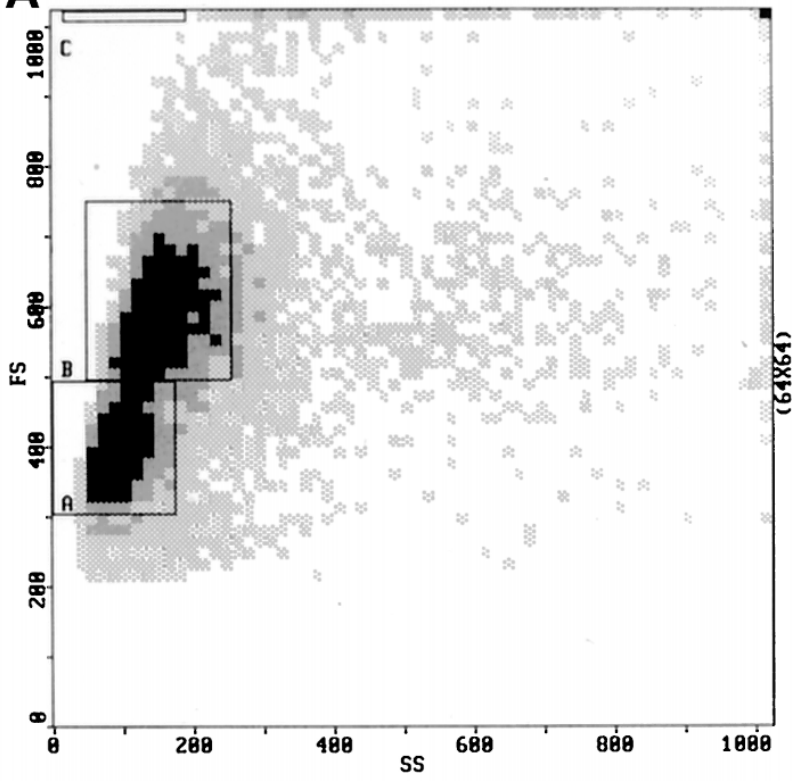

B

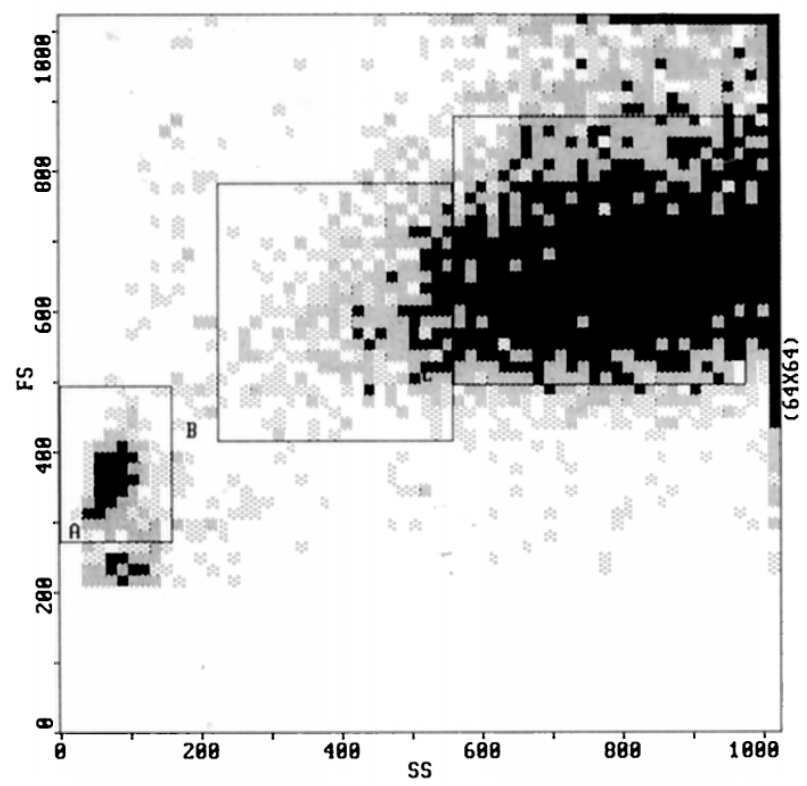

FIGURE 5. The flow cytometric analysis and the bone marrow biopsies of patient 5 before and after the first cycle of $\mathrm{As}_{2} \mathrm{O}_{3}$ treatment. A, forward versus side scatter plot of the flow cytometric analysis of a pretreatment bone marrow aspirate showing large cells with light scattering properties of myeloblasts in gate B. B, forward versus side scatter plot of the flow cytometric analysis of a bone marrow aspirate after first cycle of $\mathrm{As}_{2} \mathrm{O}_{3}$ treatment showing a predominant population of cells compatible with myelocytes in gate $\mathrm{C}$.

In contrast to conventional cytotoxic chemotherapy that causes myelosuppression, $\mathrm{As}_{2} \mathrm{O}_{3}$ at low doses $(0.1 \mathrm{mg} / \mathrm{kg} /$ day) had no myelosuppressive effect, and instead induced significant leukocytosis in three of the five patients during the first 2 to 4 weeks of induction. One distinctive aspect of $\mathrm{As}_{2} \mathrm{O}_{3}$ treatment was the replacement of the myeloblasts and dysplastic promyelocytes by cells showing slightly shrunken nuclei, condensed chromatin, and significantly in- creased amounts of cytoplasm containing sparse neutrophilic granules. On flow cytometric analysis, these cells exhibited a marked increase both in cellular size and granularity, along with increased expression of CD11b (an antigen expressed on mature myeloid cells), but with decreased expression of CD33, which is typically expressed in early or intermediately differentiated myeloid cells. Although the morphology and immunophenotype does not correspond precisely with any normal stage of myeloid differentiation, the cells most closely resemble hypogranulated myelocytes. Cells with a similar immunophenotype were previously described as "intermediate cells" in APL patients treated with ATRA therapy (3). These atypical myelocytes still carry the $t(15 ; 17)$ translocation and therefore represent partially differentiated APL cells. However, after the completion of two cycles of $\mathrm{As}_{2} \mathrm{O}_{3}$ treatment, these atypical myelocytes disappeared in two patients and normal trilineage hematopoiesis resumed with no detectable $\mathrm{t}(15 ; 17)$ translocation or PML-RARa fusion transcripts. Similar findings have also been reported by Chen et al. (6). Interestingly, significant dyserythropoiesis commonly observed in patients with arsenic intoxication was not seen in those APL patients treated with $\mathrm{As}_{2} \mathrm{O}_{3}$. It appears that at higher doses arsenic can also trigger cell death, as treatment with high doses of $\mathrm{As}_{2} \mathrm{O}_{3}(0.4 \mathrm{mg} / \mathrm{kg} /$ day $)$ (patient 1) resulted in significant bone marrow necrosis. Interestingly, the same phenomenon has also reported in patients treated with ATRA used at standard doses (18).

One finding observed in this study was the appearance of sheets of atypical promyelocytes in the bone marrow following therapy that did not represent residual disease. After two cycles of $\mathrm{As}_{2} \mathrm{O}_{3}$ therapy, patient 4 showed sheets of these cells, although both the cytogenetic analysis and RT-PCR for PML/RAR $\alpha$ performed on the same marrow aspirate were negative. The presence of frequent prominent nucleoli in these atypical promyelocytes raised the possibility of persistent APL. However, unlike usual dysplastic APL cells that often exhibit irregular nuclear contours or bilobed nuclei, these atypical promyelocytes had smooth oval to round nuclear contours and abundant granular cytoplasm. Furthermore, on the subsequent bone marrow biopsy one month later these cells were not seen and there was no evidence of leukemia. All the hematologic and clinical parameters were normal, and the cytogenetics as well as molecular analysis remain negative. Similar atypical promyelocytes were also seen on the bone marrow of patient 3 after the third cycle of $\mathrm{As}_{2} \mathrm{O}_{3}$ therapy when the patient was in molecular remission based on the negative result of RT-PCR for PML/RAR $\alpha$.

Although several clinical studies in China (6-7) as well as in the United States (8) have proved the clinical effectiveness of $\mathrm{As}_{2} \mathrm{O}_{3}$ therapy for both 
ATRA-sensitive and -resistant APL, its antileukemic mechanism is still not fully understood. Both in vitro and in vivo studies by Chen et al. (6) suggested two mechanisms of action for $\mathrm{As}_{2} \mathrm{O}_{3}$. At low concentrations, $\mathrm{As}_{2} \mathrm{O}_{3}$ induces partial differentiation of APL cells, whereas at high concentrations this drug appears to trigger apoptosis. This suggested mode of $\mathrm{As}_{2} \mathrm{O}_{3}$ action appears supported by our morphologic findings on patient 1 , showing alternating hypercellularity and necrosis on the bone marrow after treatment with higher doses of $\mathrm{As}_{2} \mathrm{O}_{3}$. Most in vitro studies (9-16) suggest that the action of $\mathrm{As}_{2} \mathrm{O}_{3}$ is primarily mediated through triggering apoptosis of APL cells, in association with down-regulation of bcl-2 protein and degradation of PML/RAR $\alpha$. As previously reported (19), our immunofluorescent staining on one case in this series showed that $\mathrm{As}_{2} \mathrm{O}_{3}$ induces rapid reorganization of dispersed microparticulate pattern of PML nuclear structures into two to four large aggregates (data not shown). Whether this reorganization of PML structures is critical for responsiveness to $\mathrm{As}_{2} \mathrm{O}_{3}$ remains to be seen.

\section{REFERENCES}

1. Warrell RP Jr, de The H, Wang Z-Y, Degos L. Acute promyelocytic leukemia. N Engl J Med 1993;329:177-89.

2. Fenaux P, Chomienne C. Biology and treatment of acute promyelocytic leukemia. Curr Opin Oncol 1996;8:3-12.

3. Warrell RP Jr, Frankel SR, Miller WH Jr, Scheinberg DA, Itri $\mathrm{LM}$, Hittelman WN, et al. Differentiation therapy of acute promyelocytic leukemia with tretinoin (all-trans-retinoic acid). N Engl J Med 1991;324:1385-93.

4. Coco FL, Nervi C, Avvisati G, Mandelli F. Acute promyelocytic leukemia: a curable disease. Leukemia 1998;12:186680 .

5. Tallman MS. Therapy of acute promyelocytic leukemia: alltrans retinoic acid and beyond. Leukemia 1998;12(1 Suppl): S37-S40.

6. Chen G-Q, Shi X-G, Tang W, Xiong S-M, Zhu J, Cai X, et al. Use of arsenic trioxide $\left(\mathrm{As}_{2} \mathrm{O}_{3}\right)$ in the treatment of acute promyelocytic leukemia (APL): I. $\mathrm{As}_{2} \mathrm{O}_{3}$ exerts dosedependent dual effects on APL cells. Blood 1997;89:3345-53.

7. Shen Z-X, Chen G-Q, Ni J-H, Li X-S, Xiong S-M, Qiu Q-Y, et al. Use of arsenic trioxide $\left(\mathrm{As}_{2} \mathrm{O}_{3}\right)$ in the treatment of acute promyelocytic leukemia (APL): II. Clinical efficacy and phar- macokinetics in relapsed patients. Blood 1997;89:3354-60.

8. Soignet SL, Maslak P, Wang Z-G, Jhanwar S, Calleja E, Dardashti LJ, et al. Complete remission after treatment of acute promyelocytic leukemia with arsenic trioxide. N Engl J Med 1998;339:1341-8.

9. Chen G-Q, Zhu J, Shi X-G, Ni J-H, Zhong H-J, Si G-Y, et al. In vitro studies on cellular on cellular and molecular mechanisms of arsenic trioxide $\left(\mathrm{As}_{2} \mathrm{O}_{3}\right)$ in the treatment of acute promyelocytic leukemia: $\mathrm{As}_{2} \mathrm{O}_{3}$ induces $\mathrm{NB}_{4}$ cell apoptosis with down-regulation of Bcl-2 expression and modulation of PML-RAR $\alpha$ /PML proteins. Blood 1996;88:1052-61.

10. Shao W, Fanelli M, Ferrara FF, Riccioni R, Rosenauer A, Davison $\mathrm{K}$, et al. Arsenic trioxide as an inducer of apoptosis and loss of PML/RAR $\alpha$ protein in acute promyelocytic leukemia cells. J Natl Cancer Inst 1998;90:124-33.

11. Muller S, Matunis MJ, Dejean A. Conjugation with the ubiquitin-related modifier SUMO-1 regulates the partitioning of PML within the nucleus. EMBO J 1998;17:61-70.

12. Gianni M, Koken MHM, Chelbi-Alix MK, Benoit G, Lanotte $\mathrm{M}$, Chen Z, et al. Combined arsenic and retinoic acid treatment enhances differentiation and apoptosis in arsenicresistant NB4 cells. Blood 1998;91:4300-10.

13. Akao Y, Mizoguchi H, Kojima S, Naoe T, Ohishi N, Yagi K. Arsenic induces apoptosis in B-cell leukemic cell lines in vitro: activation of caspases and down-regulation of Bcl-2 protein. Br J Haematol 1998;102:1055-60.

14. Wang Z-G, Rivi R, Delva L, Konig A, Scheinberg DA, Gambacorti-Passerini C, et al. Arsenic trioxide and melarsoprol induce programmed cell death in myeloid leukemia cell lines and function in a PML and PML-RAR $\alpha$ independent manner. Blood 1998;92:1497-504.

15. Zhu J, Koken MHM, Quignon F, Chelbi-Alix MK, Degos L, Wang ZY, et al. Arsenic-induced PML targeting onto nuclear bodies: implications for the treatment of acute promyelocytic leukemia. Proc Natl Acad Sci U S A 1997;94:3978-83.

16. Look AT. Arsenic and apoptosis in the treatment of acute promyelocytic leukemia [editorial]. J Natl Cancer Inst 1998; 90:86-8.

17. Miller WH Jr, Kakizuka A, Frankel SR, Warrell RP Jr, DeBlasio A, Levine $\mathrm{K}$, et al. Reverse transcription polymerase chain reaction for the rearranged retinoic acid receptor $\alpha$ clarifies diagnosis and detects minimal residual disease in acute promyelocytic leukemia. Proc Natl Acad Sci U S A 1992;89: 2694-8.

18. Limentani SA, Pretell JO, Potter D, DuBois JS, Daoust PR, Spieler PS, et al. Bone marrow necrosis in two patients with acute promyelocytic leukemia during treatment with alltrans retinoic acid. Am J Hematol 1994;47:50-5.

19. Westervelt P, Pollock J, Haug J, Ley TJ, DiPersio JF. Response and toxicity associated with dose escalation of arsenic trioxide in the treatment of resistant acute promyelocytic leukemia [abstract]. Blood 1997;90(1 Suppl);A3859. 